\title{
THE EFFICACY OF AN INFUSION OF BINAHONG LEAVES (ANREDERA CORDIFOLIA (TEN.) STEENIS) AGAINST WILD STRAIN BLACK-PIGMENTED BACTERIA
}

\author{
VIVIAN WIJAYA, ELIZABETH SHINTA MAHARANI, HARUN ASYIQ GUNAWAN, RIA PUSPITAWATI*
}

Department of Oral Biology, Faculty of Dentistry, Universitas Indonesia, Jakarta, Indonesia. Email: rpuspitawati2013@gmail.com

Received: 16 September 2017, Revised and Accepted: 3 October 2017

\section{ABSTRACT}

Objective: Black-pigmented bacteria represent one of the most prominent causes of chronic periodontitis. The objective of this study is to investigate the in vitro antibacterial effect of an infusion of binahong leaves (Anredera cordifolia (Ten.) Steenis) against black-pigmented bacteria.

Methods: The black-pigmented bacteria were isolated from the periodontal pocket of a patient with chronic periodontitis. The minimum inhibitory concentration (MIC) and minimum bactericidal concentration (MBC) were determined by means of a dilution test using $10^{5} \mathrm{cfu} / \mathrm{ml}$ of bacteria cultured on Brucella broth containing blood and kanamycin, which was exposed to a $20 \%, 30 \%, 40 \%, 50 \%, 65 \%, 80 \%$, and $95 \%$ infusion of binahong leaves and then incubated for 24,48 , and $72 \mathrm{~h}$. In the blank disc diffusion test, a $50 \%, 65 \%, 80 \%, 95 \%$, and $100 \%$ infusion was dripped onto a paper disc placed at the center of a Brucella agar bacterial culture and then incubated for $24 \mathrm{~h}$.

Results: The MIC and MBC of the binahong leaf infusion were $>65 \%$ and $80 \%$, respectively, while the antibacterial activity was not correlated with the duration of the exposure to the infusion. The diffusion test showed that an increased concentration of the infusion resulted in an increased diameter of the inhibition zone that ranged from $0.42 \mathrm{~mm}$ ( $50 \%$ infusion) to $1.42 \mathrm{~mm}$ (100\% infusion).

Conclusion: Binahong leaves infusion has potential efficacy against black-pigmented bacteria.

Keywords: Binahong leaves infusion, Black-pigmented bacteria, Chronic periodontitis.

(C) 2017 The Authors. Published by Innovare Academic Sciences Pvt Ltd. This is an open access article under the CC BY license (http://creativecommons. org/licenses/by/4. 0/) DOI: http://dx.doi.org/10.22159/ijap.2017.v9s2.08

\section{INTRODUCTION}

The loss of dental attachment and alveolar bone destruction that occur in cases of periodontitis is caused by the inflammation response of the host tissues against the toxin produced by bacteria [1]. Based on their degree of virulence, the periodontopathogens can be classified into six groups. Indeed, from the most to the least virulent, the periodontopathogenic bacteria groups are red complex, orange complex, yellow complex, green complex, blue complex, and purple complex. The red and orange complex bacteria have a strong relationship with the clinical parameters commonly used as a reference in the diagnosis of periodontitis. The red complex bacteria group consists of Treponema denticola, Porphyromonas gingivalis, and Bacteroides forsythus, while the orange complex bacteria group includes Prevotella intermedia, Prevotella nigrescens, and some others species [2].

The bacteria most commonly found in cases of chronic periodontitis are P. gingivalis (red complex) and P. intermedia (orange complex) [3]. These two bacteria together comprise a class of periodontopathogens known as black-pigmented bacteria. These bacteria are referred to as black-pigmented bacteria because both groups produce melanin and appear as black-pigmented colonies [4].

Indonesia is a country rich in various plants, and hence, the government had instituted a policy of developing the potentiation of herbal medicine derived from traditional medicinal herbs [5]. Binahong (Anredera cordifolia (Ten.) Steenis) has long been widely used by the Indonesian population as a traditional medicine. Phytochemical filtration has shown that the active ingredients of binahong are phenol, flavonoids, terpenoids, and steroids.

The highest phenol content in binahong is found (from the highest to the lowest) in the flower, leaves, and root of the plant. Binahong leaves also contain alkaloids and saponins. Binahong leaves represent the easiest part of the plant to harvest in large quantities, and the flavonoid content is high [6]. The flavonoids and saponins found in plants are famous for their antibacterial effect due to their capability for degrading the permeability of the bacterial cell wall $[7,8]$. A previous study reported that an extract of binahong leaves had an antibacterial effect against Staphylococcus aureus, showing a minimum inhibitory concentration (MIC) and a minimum bactericidal concentration (MBC) of $25 \%$ and $50 \%$, respectively [9].

Another study reported both the MIC and MBC of an infusion of binahong leaves against Streptococcus mutans to be 50\% [10]. S. aureus and S. mutans are Gram-positive bacteria, while the black-pigmented bacteria are Gram-negative microorganisms, which are more resistant than the Gram-positive class [11].

Chlorhexidine is the most common antibacterial agent used in the treatment of periodontitis. It has been proven to be clinically effective in overcoming many cases of chronic periodontitis [12]. However, the availability of this agent as well as other synthetic antibacterial agents in various isolated and remote regions of Indonesia remains limited.

The simplest way of making use of herbal plants is the creation of an infusion. The infusion technique requires a lower temperature than the boiling and steaming involved in processing herbal medicines, which means it does not lead to any damage to the plant's active components. Further, the technique does not require any sophisticated tools or techniques, meaning that it can be practised by the wider community $[12,13]$.

This study aimed to investigate the antibacterial effect of an infusion of binahong leaves against black-pigmented bacteria.

\section{METHODS}

Handling of the wild strain black-pigmented bacteria sample The sample of black-pigmented bacteria used in this study was isolated from a chronic periodontitis patient before the delivery of any treatment. 
The patient agreed to be a research subject by signing an informed consent form. The wild strain black-pigmented bacteria were collected from subgingival plaque extracted from a $5 \mathrm{~mm}$ dental pocket, which was then soaked in $1 \mathrm{ml}$ of phosphate-buffered saline and centrifuged at $700 \mathrm{rpm}, 800 \mathrm{rpm}$, and $900 \mathrm{rpm}$ for $1 \mathrm{~min}$ each. The resultant pellet was diluted in $1 \mathrm{ml}$ of $\mathrm{NaCl}$, homogenized with an Eppendorf pipet, cultured on Brucella agar with the addition of $\mathrm{N}_{2} \mathrm{H}_{2} \mathrm{CO}_{2}$ gas, and then, incubated for $3 \times 24 \mathrm{~h}$ at $37^{\circ} \mathrm{C}$. After incubation for $3 \times 24 \mathrm{~h}$, the colonies featuring the typical morphology of black-pigmented bacteria were isolated, so they could be tested using the gram fixation technique. The colonies confirmed as black-pigmented bacteria were then cultured on Brucella broth containing kanamycin and incubated for $6 \times 24 \mathrm{~h}$ in an anaerobic environment. The bacterial culture was then gradually diluted up to $1.05 \times 10^{5} \mathrm{cfu} / \mathrm{ml}$.

\section{Binahong leaf infusion}

The binahong plant (A. cordifolia (Ten.) Steenis subspecies Cordifolia) used in this study had previously been verified by the Herbarium Laboratorium SITH Bandung Institute of Technology. $50 \mathrm{~g}$ of binahong leaves were washed and dried in the open air, chopped, and then kept in a glass cup containing $500 \mathrm{ml}$ of aquabidest. The mixture was steamed at $100^{\circ} \mathrm{C}$ for $15 \mathrm{~min}$, before being filtered with mesh covered by a cloth to obtain a $10 \%$ binahong leaf infusion. The infusion was then steamed in an open jar placed on a $100^{\circ} \mathrm{C}$ water bath until one-tenth of the volume of the $10 \%$ infusion remained. This resulted in a $100 \%$ infusion, which was kept in an air-free glass jar sealed with aluminum foil. After $24 \mathrm{~h}$, the infusion was tyndalized for three consecutive days by means of $30 \mathrm{~min}$ steaming in a $60^{\circ} \mathrm{C}$ water bath so as to terminate all the microbial spores that might be present in the infusion. The $100 \%$ infusion was then diluted in Brucella broth containing kanamycin to obtain $20 \%, 30 \%, 40 \%, 50 \%, 65 \%, 80 \%$, and $95 \%$ concentrations for each concentration tested, and a $2 \mathrm{ml}$ infusion was used.

\section{Dilution test}

The dilution test was conducted in two phases by adding various concentrations of the binahong leaf infusion to the BHI liquid and black-pigmented bacterial suspension. The first phase used the $20 \%$, $30 \%, 40 \%$, and $50 \%$ infusions, while the second phase used the $50 \%$, $65 \%, 80 \%$, and $95 \%$ infusions. The dilution test was conducted in triplicate for each concentration. All the samples were incubated in an anaerobic jar (an air-free jar filled with $\mathrm{N}_{2} \mathrm{H}_{2} \mathrm{CO}_{2}$ gas) at $37^{\circ} \mathrm{C}$ for $24 \mathrm{~h}$. Visual observations were performed after 24,48 , and $72 \mathrm{~h}$, followed by a scratch test on Brucella agar to determine the MIC and MBC of the infusion.

As a positive control, $0.5 \mathrm{ml}$ of Brucella broth with kanamycin was added to $1.5 \mathrm{ml}$ of $0.2 \%$ chlorhexidine and $1.05 \times 10^{5} \mathrm{cfu} / \mathrm{ml}$ of bacterial suspension. The negative control was $2 \mathrm{ml}$ of Brucella broth with kanamycin and $1.05 \times 10^{5} \mathrm{cfu} / \mathrm{ml}$ of bacterial suspension.

The independent variables in the dilution test were the concentration of the binahong leaf infusion and the duration of the bacterial culture's exposure to the binahong infusion.

\section{Diffusion test}

Round paper discs were placed at the center of a Brucella agar medium set on Petri discs. The black-pigmented bacteria suspension $\left(1.05 \times 10^{5} \mathrm{cfu} / \mathrm{ml}\right)$ was cultured on the surface of the Brucella agar away from the paper disc and then incubated at $37^{\circ} \mathrm{C}$ for $15 \mathrm{~min}$ in an anaerobic jar. The various concentrations of the binahong leaf infusion $(96 \%, 80 \%, 65 \%$, and $50 \%)$ were then dripped onto the paper discs $\left(0.2 \mathrm{ml}\right.$ of each) and incubated at $37^{\circ} \mathrm{C}$ for $24 \mathrm{~h}$ in an anaerobic jar. The diffusion test was conducted in duplicate for each binahong leaf concentration tested. The measurement of the inhibition zone was performed in millimeter using a gauge caliper following the formulae $(t-d): 2$, where $t$ is the diameter of the clear zone and $d$ is the diameter of the paper disc. The inhibition zone is the result of half the difference between the clear zone's diameter and the paper disc's diameter (Fig. 1).

\section{RESULTS}

An examination of the bacterial culture on the Brucella agar after $3 \times 24 \mathrm{~h}$ incubation showed that the colonies growing on the media matched the characteristics of black-pigmented bacteria, namely, a blackish brown color, rounded shape, and smooth but rather convex surface. This appearance was confirmed by the results of the gram fixation test, which showed a violet color, indicating Gram-negative bacteria. An examination using a $\times 100$ magnification microscope showed that the bacteria exhibited similar morphology to blackpigmented bacteria (Fig. 2)

\section{Results of the dilution test}

The antibacterial effect of the binahong leaf infusion against blackpigmented bacteria was tested using the dilution test, the results of which can be seen in Table 1 . There was no visible difference in turbidity between the black-pigmented cultures exposed to the binahong leaf infusion for 24 (sample 1), 48 (sample 2), and $72 \mathrm{~h}$ (sample 3). The visual turbidity was marked as positive (+), while the clearness was marked as negative (-). The positive control consisted of

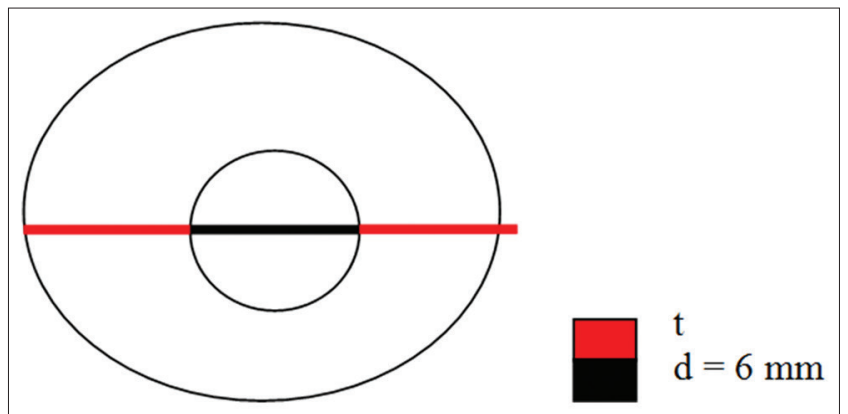

Fig. 1 Schematic drawing of inhibition zone measurement

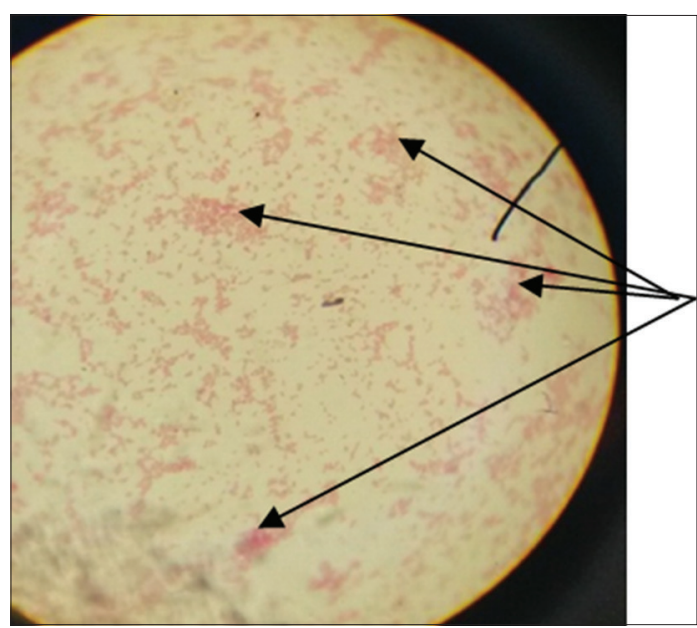

Fig. 2: The gram fixation test showed violet colonies. The arrows point to big colonies among other smaller ones

Table 1: Visual observation of the dilution test of the binahong leaf infusion after 24,48 , and $72 \mathrm{~h}$

\begin{tabular}{|c|c|c|c|c|c|c|c|}
\hline \multirow{2}{*}{$\begin{array}{l}\text { Groups } \\
\text { studied }\end{array}$} & \multicolumn{7}{|c|}{ Concentration (\%) } \\
\hline & 20 & 30 & 40 & 50 & 65 & 80 & 95 \\
\hline \multicolumn{8}{|l|}{ Sample } \\
\hline 1 & + & + & + & + & + & + & + \\
\hline 2 & + & + & + & + & + & + & + \\
\hline 3 & + & + & + & + & + & + & + \\
\hline Control (+) & + & + & + & + & + & + & + \\
\hline Control (-) & + & + & + & + & + & + & + \\
\hline
\end{tabular}


$1.5 \mathrm{ml}$ of chlorhexidine with $0.5 \mathrm{ml}$ of Brucella broth and $0.5 \mathrm{ml}$ of blackpigmented suspension $\left(1.05 \times 10^{5} \mathrm{cfu} / \mathrm{ml}\right)$, while the negative control consisted of $2 \mathrm{ml}$ of Brucella broth with black-pigmented suspension $\left(1.05 \times 10^{5} \mathrm{cfu} / \mathrm{ml}\right)$. In the dilution test, no difference in turbidity could be detected between the different groups.

Table 2 presents the results of the scratch test of the binahong leaf infusion, which was performed to determine the MIC and MBC based on the presence of black-pigmented colonies on each culture exposed to various concentrations of the binahong infusion. There was no difference detected between the groups with different incubation durations: 24 (sample 1), 48 (sample 2), and 72 (sample 3) h.

As can be seen from Table 2, there were no colonies of black-pigmented bacteria detected on the positive control groups. Conversely, on the negative control groups, black-pigmented colonies could be seen on all the cultures exposed to all the different concentrations of the binahong leaf infusion. For all the different incubation periods, the MBC of the binahong leaf infusion was determined to be $80 \%$, while the MIC could not be determined.

\section{Results of the diffusion test}

Based on the diffusion test, the inhibition zone of the binahong leaf infusion could be determined. The results are presented in Table 3 .

The results of the diffusion test showed a trend of an increased inhibition effect of the binahong leaf infusion against black-pigmented bacteria with an increased concentration of the infusion. However, even at a $100 \%$ concentration, the inhibition effect of the binahong leaf infusion was still below that of chlorhexidine.

\section{DISCUSSION}

The media used in this study to culture black-pigmented bacteria were Brucella broth and Brucella agar supplemented with blood, Vitamin $\mathrm{K}$, and hemin, which are suitable for growing anaerobic bacteria [14]. Brucella is a good medium for culturing Gram-negative bacteria, while vitamin $\mathrm{K}$ and hemin are necessary supplements due to their role as growth factors. Kanamycin is an aminoglycoside antibiotic that is effective against Gram-positive bacteria such as Staphylococcus, Streptococcus, and Enterococcus as well as several Gram-negative bacteria such as Enterobacter and Pseudomonas [15]. Kanamycin supplementation in the medium is important because kanamycinBrucella agar with blood is a selective medium for Gram-negative anaerobic obligate bacteria.

Table 2: Results of the scratch test on Brucella agar after 24, 48, and $72 \mathrm{~h}$

\begin{tabular}{llllllll}
\hline \multirow{2}{*}{$\begin{array}{l}\text { Groups } \\
\text { studied }\end{array}$} & \multicolumn{7}{c}{ Concentration (\%) } \\
\cline { 2 - 7 } & $\mathbf{2 0}$ & $\mathbf{3 0}$ & $\mathbf{4 0}$ & $\mathbf{5 0}$ & $\mathbf{6 5}$ & $\mathbf{8 0}$ & $\mathbf{9 5}$ \\
\hline Sample & & & & & & & \\
1 & + & + & + & + & + & - & - \\
2 & + & + & + & + & + & - & - \\
3 & + & + & + & + & + & - & - \\
Control (+) & - & - & - & - & - & - & - \\
Control (-) & + & + & + & + & + & + & + \\
\hline
\end{tabular}

The dilution test performed in this study showed that, after 24, 48, and $72 \mathrm{~h}$ of incubation, all the groups exposed to $20-95 \%$ binahong leaf infusion showed similar turbidity, which indicates that the turbidity was more likely due to the dark color of the infusion. Therefore, the MIC could not be determined by the dilution test, and hence, needed to be confirmed by a scratch test performed on a Brucella agar medium. The results of the scratch test showed no difference in bacterial growth between the cultures incubated for 24,48 , or $72 \mathrm{~h}$. Such results indicate that there is no correlation between the duration of exposure to the infusion and its antibacterial effect. There was no difference in the density of the bacterial colonies that grew in cultures exposed to a $20-65 \%$ infusion. Meanwhile, on those cultures exposed to a $\geq 80 \%$ infusion, no single colony could be detected. Therefore, it is very likely that the MIC of the infusion lies between $65 \%$ and $80 \%$. The MBC could be determined at an $80 \%$ concentration.

The efficacy of the binahong infusion as an antibacterial agent could be due to its active components, including phenol, flavonoids, alkaloids, terpenoids, and saponins. Flavonoids, which have been proven to be the main component of phenol, are known to be capable of inhibiting the synthesis of microorganism DNA and RNA [16]. The terpenoid component of binahong is also known to be capable of inhibiting bacterial growth by increasing the permeability of the bacterial cell wall. Similarly, the saponins and alkaloids could also lead to the lysis of the bacterial cell wall or imperfect bacterial cell wall formation [17]

The results of this study showed that the MBC of the binahong infusion occurred at an $80 \%$ concentration. Such a high MBC concentration might reflect the weak antibacterial effect of binahong in the form of an infusion. Although an infusion is the most suitable form for preparing the soft parts of plants such as the leaves and flowers [16], and while the preparation procedure is simple and economic, the efficacy of a binahong infusion is not as strong as that of binahong extract. A previous study reported that the MIC and MBC of binahong extract were $25 \%$ and $50 \%$, respectively [10]. Another possible explanation for the high antibacterial concentration of the binahong infusion as found in this study might be related to the class of bacteria used, namely, Gram-negative bacteria, which is known to be more resistant than Gram-positive bacteria. A previous study reported that the MBC of binahong extract against $S$. aureus, which is a Gram-positive bacteria, was $50 \%$, while against Pseudomonas aeruginosa, which is a Gramnegative bacteria, it was $100 \%$ [9].

This study also showed that the inhibition zone produced by exposure to a binahong leaf infusion was increased as the concentration of the infusion increased. The concentration is one of many factors that influence the activity of antibacterial agents. The increment of the active component of the concentration could lead to the stronger penetration of that component into the bacterial cells [18].

\section{CONCLUSION}

The binahong leaf infusion has an antibacterial effect against blackpigmented bacteria, with an MIC at $>65 \%$, an MBC at $80 \%$, and an inhibition zone at $>50 \%$. Further, the inhibition effect of the binahong leaf infusion increases as the concentration increases. However, there is no correlation between the duration of exposure and the antibacterial effect of the binahong leaf infusion.

Table 3: Inhibition zone of the binahong leaf infusion against black-pigmented bacteria

\begin{tabular}{llll}
\hline Infusion concentration (\%) & $\mathbf{1}^{\text {st }}$ experiment $\mathbf{( m m )}$ & $\mathbf{2}^{\text {nd }}$ experiment $(\mathbf{m m})$ & Mean inhibition zone $(\mathbf{m m})$ \\
\hline 50 & 0.59 & 0.25 & 0.42 \\
65 & 1.21 & 1.21 & 1.21 \\
80 & 0.62 & 1.74 & 1.18 \\
95 & 0.99 & 1.38 & 1.19 \\
100 & 1.36 & 1.36 & 3.7 \\
Chlorhexidine 0.2 & 4.49 & 2.91 & 0 \\
Aquadest & 0 & 0 & \\
\hline
\end{tabular}




\section{ACKNOWLEDGEMENT}

The publication of this manuscript is supported by Universitas Indonesia.

\section{REFERENCES}

1. Mewman MG. Carranza's Clinical Periodontology. 11 ${ }^{\text {th }}$ ed. China: Elsevier Inc.; 2012.

2. López R, Dahlén G, Retamales C, Baelum V. Clustering of subgingival microbial species in adolescents with periodontitis. Eur J Oral Sci 2011;119:141-50.

3. Mane A, Karmarkar A, Bharadwaj R. Anaerobic bacteria in subjects with chronic periodontitis and in periodontal health. J Oral Health Community Dent 2009;3:49-51.

4. Samaranayake L. Essential Microbiology for Dentistry. $3^{\text {rd }}$ ed. Philadelphia, PA: Elsevier Inc.; 2006.

5. Kebijakan Program Pengembangan Pusat Pengolahan Pasca Panen Tanaman Obat. Available from: http://www.binfar.depkes.go.id/v2/wpcontent/uploads/2014/05/P4TO-Rakontek-2014.pdf. [Last accessed on 2014 Sep 12].

6. Asmariati Y, Busman H, Susantiningsih T. Protective effect of binahong leaf (Anredera cordifolia (Ten.) steenis) extract against ethanol-induced proximal tubule renal histopathological features of sprague-dawley strain white rats. Med J Lampung Univ 2014;3(3):168-77.

7. Cushnie TP, Lamb AJ. Antimicrobial activity of flavonoids. Int J Antimicrob Agents 2005;26:343-56.

8. Djamil R, Wahyudi PS, Wahona S, Hanafi M. Antioxidant activity of flavonoid from Anredera cordifolia (Ten.) steenis leaves. Int Res J Pharm 2012;3:241-3
9. Khunaefi M. Uji Aktifitas Ekstrak Daun Binahong (Anredera cordifolia (Tens.) Steenis) Terhadap Bakteri Staphylococcus aureus Dan Pseudomonas aerugenosa, Undergraduate Thesis. Malang: Universitas Islam Negeri Maulana Malik Ibrahim; 2010.

10. Lakhsmi V. Efek Antimicroba Infusum Daun Binahong (Anredera cordifolia (Ten.) Steenis) Terhadap Bakteri Streptococcus mutans, Uji KHM dan KBM, Undergraduate Thesis, Universitas Indonesia; 2014.

11. Biswas B, Rogers K, McLaughlin F, Daniels D, Yadav A. Antimicrobial activities of leaf extract of Guava (Psidium guajava L.) on two gramnegative and gram-positive bacteria. Int J Microbiol 2013;2013:1-7.

12. Departemen Kesehatan Republik Indonesia. Farmakope Indonesia. $5^{\text {th }}$ ed. Jakarta: Departemen Kesehatan Republik Indonesia; 1996.

13. Ríos JL, Recio MC. Medicinal plants and antimicrobial activity. J Ethnopharmacol 2005;100:80-4.

14. Remel Brucella Agar with 5\% Sheep Blood, Hemin, Vitamin K, IFU 4012. Available from: https://www.tools.thermofisher.com/content/sfs/ manuals/IFU1254.pdf. [Last accessed on Sep 12].

15. Hauser AR. Aminoglycosides in Antibiotic Basics for Clinicians: The ABCS of Choosing the Right Antimicrobial Agent. $2^{\text {nd }}$ ed. Philadelphia, PA: Wolters Kluwer; 2013

16. Badan Pengawas Obat dan Makanan RI. Acuan Sediaan Bahan Herbal. $5^{\text {th }}$ ed. Jakarta: Direktoral Obat Asli Indonesia, Deputi Bidang Pengawasan Obat Tradisional, Badan POM RI; 2010. p. 147.

17. Darsana IG, Besung IN, Mahatmi H. Potensi daun binahong (Anredera Cordifolia (Tenore) steenis) dalam menghambat pertumbuhan bakteri Escherichia coli secara in vitro. Indones Med Vet 2012;1:337-51.

18. Cetin-Karaca H. Evaluation of Natural Antimicrobial Phenolic Compounds Against Foodborne Pathogens, University of Kentucky Master's Theses; 2011 